THE IMPACT OF DRUG POLICY ON THE ENVIRONMENT

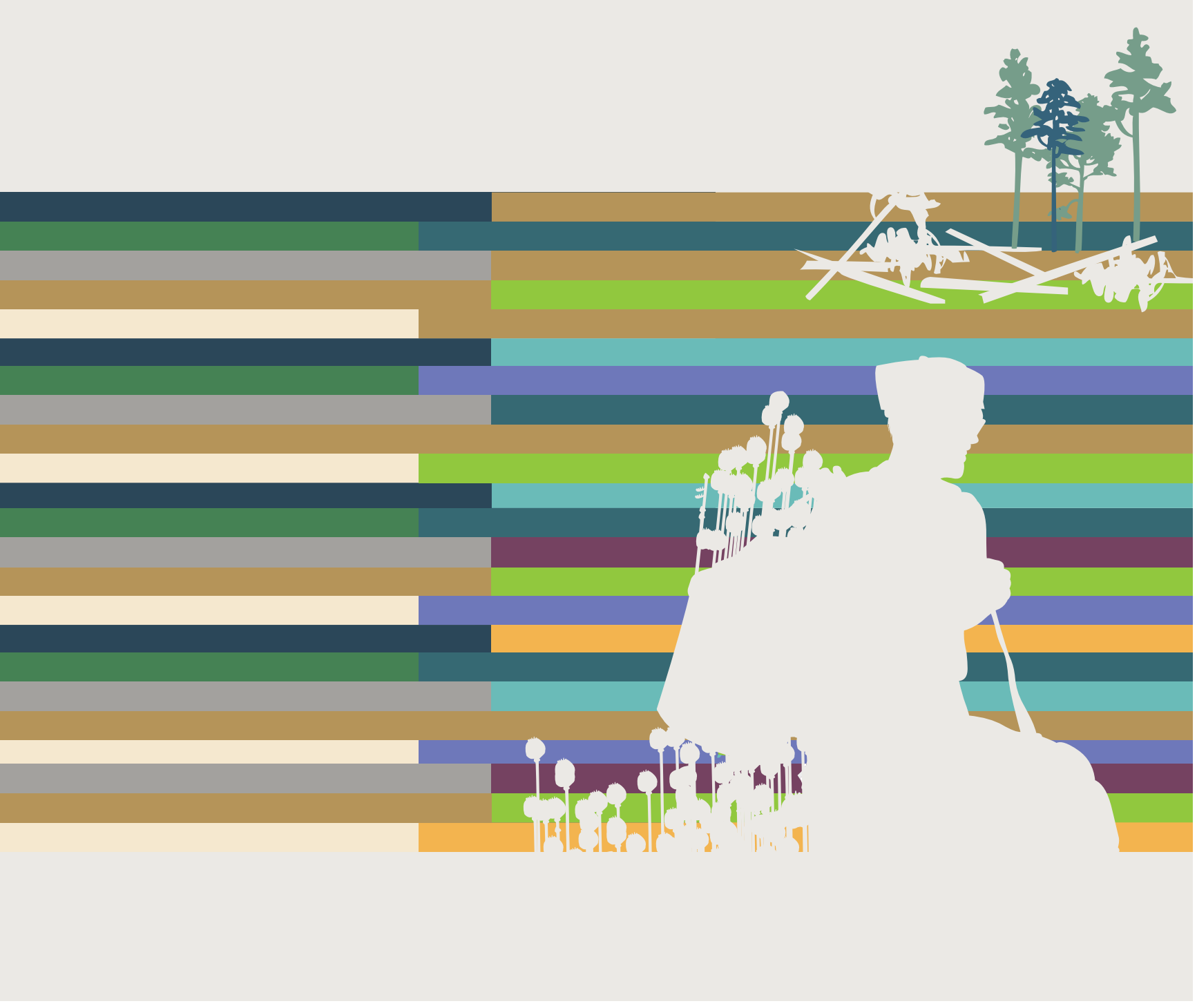

Kendra McSweeney

\title{
OPEN SOCIETY \\ FOUNDATIONS
}




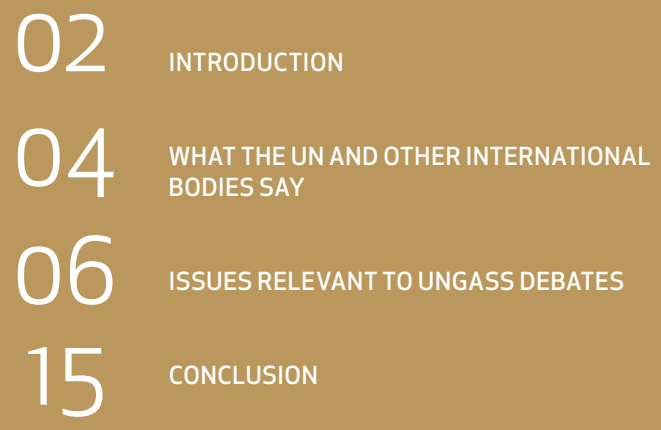

As member states of the United Nations take stock of the drug control system, a number of debates have emerged among governments about how to balance international drug laws with human rights, public health, alternatives to incarceration, and experimentation with regulation.

This series intends to provide a primer on why governments must not turn a blind eye to pressing human rights and public health impacts of current drug policies. 
This paper draws on scientific research to bring much-needed attention to the environmental costs of drug policies. It responds to recent calls by both the UN Commission on Narcotic Drugs and the Global Commission on Drug Policy for drug policy debates to be based on the latest and best empirical evidence. 


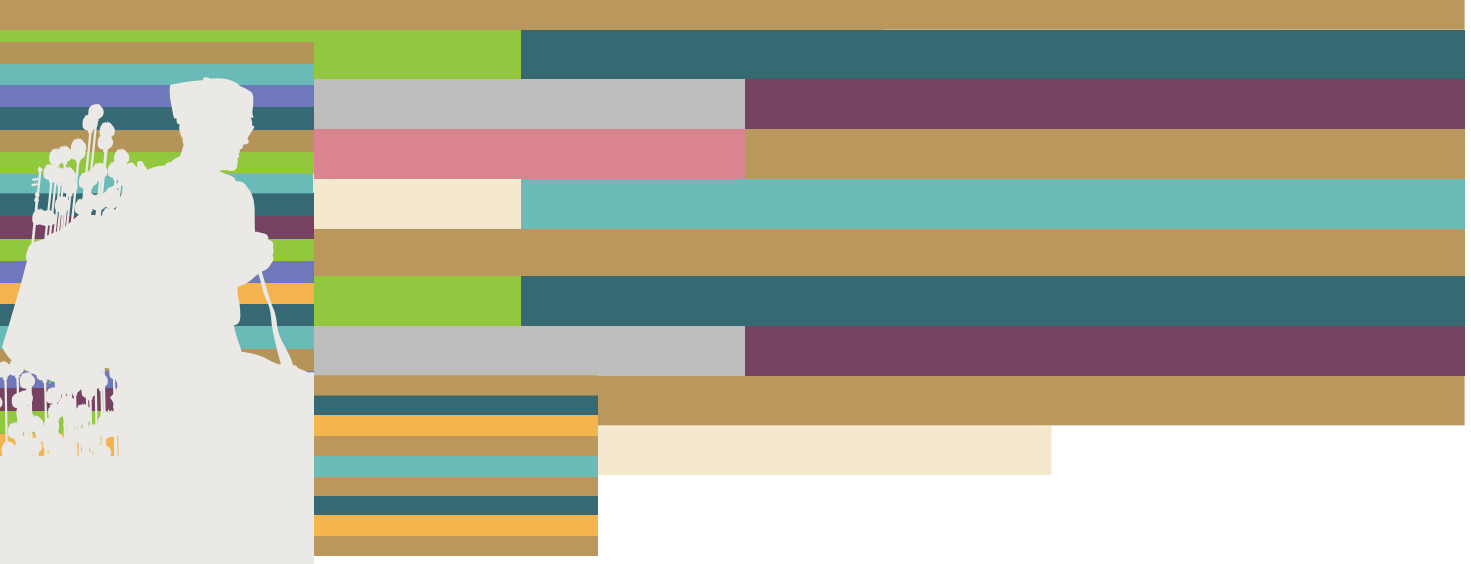

\section{INTRODUCTION}

Two apparent paradoxes lie at the heart of the relationship between illicit drugs and the environment. The first paradox is that even though the amount of land required for illicit drug crop production is tiny in global agricultural terms, ${ }^{1}$ drug crop cultivation has played a disproportionately large role in deforesting

"Drug crop eradication drives deforestation by progressively displacing drug farmers into new, more remote environments." and degrading some of the world's most biodiverse ecosystems, including those in national parks and indigenous territories. ${ }^{2}$ The second paradox is that environmental devastation is proliferating in drug trafficking regions despite sustained investments in drug interdiction and other anti-trafficking measures. How can this be?

The answer lies in understanding how drug control policies perversely harm the natural environment. Drug crop eradication drives deforestation by progressively displacing drug farmers into new, more remote environments. ${ }^{3}$ Policies to disrupt and intercept drug shipments drive forest loss and habitat destruction by incentivizing traffickers to seek out more new routes, which they often carve through biodiverse frontier regions. ${ }^{4}$ Drug prohibition, and the inevitable illegal markets associated with it, also enables traffickers to earn the grossly inflated profits that they often launder around trafficking
1 J Buxton, Drugs and Development: the Great Disconnect. Swansea University, UK: Global Drug Policy Observatory, 2015

2 UNODC, Colombia Coca Cultivation Survey 2014 Vienna: UN Office of Drugs and Crime, 2015.

3 See, e.g., A Rincón-Ruiz and G Kallis, "Caught in the Middle, Colombia's War on Drugs and its Effects on Forests and People," Geoforum 46:60-78, 2013. Eradication also typically ensures supply-side shortages, which keeps the farm-gate price for illicit crops relatively high, stimulating continued farmer involvement (see UNODC, Colombia Coca Cultivation Report, 2015; T Kramer et al, Bouncing Back: Relapse in the Golden Triangle. Amsterdam: Transnational Institute, Drugs and Democracy Program, 2014).

4 PReuter, "The Mobility of Drug Trafficking," Ending the Drug Wars, London, UK: LSE Expert Group on the Economics of Drug Policy, 2014, pp. 33-38. 
5 PKeefer, NVLoayza, RR Soares, The Development Impact of the Illegality of Drug Trade. Washington DC: World Bank, Policy Research Working Paper, 2008; KMcSweeney et al., "Drug Policy as Conservation Policy: Narco-Deforestation." Science 343 489-490, 2014; P Fearnside, "The Roles and Movements of Actors in the Deforestation of Brazilian Amazonia," Ecology and Society 13(1), 2008.

6 UN University, "Improving the Development Impact of Drugs Policy,' Meeting Note from Luncheon Roundtable. New York: UN, July 2014. Regarding the neglect of environmental issues in US domestic drug debates, see J K Carah et al. "High Time for Conservation: Adding the Environment to the Debate on Marijuana Liberalization", BioScience $65(8), 2015$, p. 828 hubs in extensive and ecologically devastating frontier ranching, logging, and agribusiness ventures, among other activities. ${ }^{5}$

Support for drug supply eradication by the United Nations Office on Drugs and Crime (UNODC) and the UN Commission on Narcotic Drugs therefore works in direct opposition to concurrent UN efforts to protect biodiversity, secure ecosystem services, ensure the rights of indigenous peoples, mitigate climate change, and promote sustainable development. Despite robust scientific evidence of the growing toll that drug policies take on the global environment, the issue has drawn insufficient attention from policymakers. If discussed at all, environmental issues tend to be debated "at the margins" of drug policy, ${ }^{6}$ and typically consider only contexts of drug crop eradication, ignoring the significant ecological impacts of drug interdiction in transit zones. As a result, the environmental costs of drug policies have been seriously underestimated and important stakeholders within and beyond the UN have been sidelined in drug policy debates.

This paper draws on scientific research to bring much-needed attention to the environmental costs of drug policies. It responds to recent calls by both the UN Commission on Narcotic Drugs and the Global Commission on Drug Policy for drug policy debates to be based on the latest and best empirical evidence. 


\section{WHAT THE UN AND OTHER INTERNATIONAL BODIES SAY}

Wide-ranging protections for the environment are included in the 1972 Declaration on the Human Environment, the 1972 Convention Concerning the Protection of the World Cultural and Natural Heritage, the 1992 Convention on Biological Diversity, and Rio Declaration on Environment and Development. The UN Declaration on the Rights of Indigenous Peoples (2007) recognizes the importance of indigenous knowledge and practice in sustainable development and environmental management, and the right of indigenous peoples to the conservation and protection of their lands and territories (Article 29). ${ }^{7}$ The draft 2015 Sustainable Development Goals include Goal 15, to "Protect, restore and promote sustainable use of terrestrial ecosystems, sustainably manage forests, combat desertification and halt and reverse land degradation, and halt biodiversity loss."8

Forests are key foci of protection. According to the 2014 UN Climate Summit New York Declaration on Forests, "Forests and the services they offer society are crucial to sustainable development and human well-being... approximately 13 million hectares of forests continue to be lost each year, contributing up to $20 \%$ of annual global greenhouse gas emissions."9 Signatories of that Declaration made a joint commitment to cut forest loss in half by 2020 and completely end it by 2030. Reducing Emissions from Deforestation and Forest Degradation (REDD) initiatives orchestrated under the UN Framework Convention on Climate Change (UNFCCC) aspire to reduce emissions from deforestation and forest degradation, create financial value for the carbon held in forest stocks, and incentivize forest conservation and management.
7 UN, United Nations Declaration on the Rights of Indigenous Peoples, New York: United Nations, 2008

8 UN, Open Working Group proposal for Sustainable Development Goals, available at: https://sustainabledevelopment.un.org/focussdgs. html, 2015

9 UN Climate Summit 2014, Action Areas-Forests, at http://www.un.org/climatechange/summit/ action-areas/

10 UNODC, United Nations Convestion against Illicit Traffic in Narcotic Drugs and Psychotropic Substances, 1988, p. 14. Available at https://www. unodc.org/pdf/convention_1988_en.pdf 
11 UNODC, World Drug Report, Vienna: UN Office on Drugs and Crime, 2015, p.107.

12 LM Dávalos, A C Bejarano, and HL Correa "Disabusing Cocaine: Pervasive Myths and Enduring Realities of a Globalised Commodity,' International Journal of Drug Policy 20:381-386, 2009; see also: A Rincón-Ruiz and G Kallis, 2013

13 UNDP, Perspectives on the Development Dimensions of Drug Control Policy, Brief, UN Development Program.

$14 \mathrm{Ibid}$. See also J Buxton, 2015
The 1988 Convention against Illicit Traffic in Narcotic Drugs calls for drug eradication measures to "take due account of... protection of the environment."10 UNODC has long documented that eradication efforts tend to displace drug production into ungoverned, resource-rich frontiers. UNODC also (separately) insists that drug crop cultivation has serious environmental impacts. The 2015 World Drug Report, for example, asserts that "the environmental impact of illicit drug production and trafficking has been broadly documented, with significant attention to the way in which illicit crops cause the degradation and destruction of primary forests in Latin America and South-East Asia."11 However, the two observations are not analytically linked. The result is that environmental concerns continue to be used as ajustification for, rather than condemnation of, continued eradication. ${ }^{2}$

Other UN agencies and multilateral organizations, in contrast, acknowledge the role of eradication policies in spreading forest loss. In a policy brief laying out issues for the 2016 UN General Assembly Special Session(UNGASS) on drugs, United Nations Development Programme (UNDP) notes that "eradication campaigns have had devastating consequences for the environment" and that fumigation campaigns "have not eradicated illicit production but rather displaced it to new areas of greater environmental significance."13 Despite the tight links between drug issues and sustainable development, UNDP notes that "drug control and development institutions have tended to operate in isolation from 
each other and in some cases, at cross-purposes."14 The brief points to the need to align drug policies more fully with development goals, and it urges the General Assembly to develop a comprehensive set of metrics to explicitly account for the broader and often unintended impacts of drug control policies on sustainable development.

Several UN agencies and other multilateral bodies, such as the Organization of American States (OAS), have described the environmental effects associated with the use of toxic defoliants in aerial fumigation campaigns..$^{15}$ The decades-long Colombian fumigation program, for example, received intense scrutiny for its collateral damages to wildlife, livestock, food crops, and the health of rural residents. ${ }^{16}$ Health concerns in particular were cited in the recent decision by Colombia to suspend aerial eradication using the defoliant glyphosate. ${ }^{17}$

OAS's 2013 report The Drug Problem in the Americas also gives some attention to the ways that trafficking-enriched criminal organizations distort rural development. The report notes that profits from trafficking are invested in rural enterprise such as cattle ranching and timber extraction. Otherwise, there appears to be widespread policy silence on the ecological impacts of drug policies in transit zones.

\section{ISSUES RELEVANT TO UNGASS DEBATES}

\section{Drug crop eradication and forests}

Because of strong evidence that cannabis, coca, and opium poppy are frequently cultivated in fields cleared from forests, eradication policies are often justified on the grounds that they are necessary to save wild lands. ${ }^{18}$ Rigorous assessments of eradication effects reject this logic. When drug fields are destroyed (whether by aerial fumigation or by hand), forest and habitat loss are typically increased, not lessened. In Colombia,
15 OAS, The Drug Problem in the Americas. Washington, DC: General Secretariat, Organization of American States, 2013

16 A Rincón-Ruiz and G Kallis, 2013

17 W Neuman, "Defying U.S., Colombia Halts Aeria Spraying of Crops used to Make Cocaine", New York Times, May 14, 2015

18 See, e.g., UNODC, World Drug Report, 2015 
19 A Rincón-Ruiz and G Kallis, 2013: Dávalos et al. 2009; UNODC, World Drug Report, 2015, p. 276

20 UNODC, Colombia Coca Cultivation Survey 2014. 2015

21 D S Salisbury and C Fagan, "Coca and Conservation: Cultivation, Eradication, and Trafficking in the Amazon Borderlands", GeoJournal 78(1):41-60, 2013 p. 57

22 UNODC, World Drug Report, 2015, p.xv.

23 B Bagley, Drug Trafficking and Organized Crime in the Americas: Major Trends in the Twenty-First Century. Washington, DC: Woodrow Wilson International Center for Scholars, Latin America Program, 2012; P Reuter, 2014.

24 For the Andes and Mexico, see OAS, 2013: Count the Costs, The War on Drugs: Causing Deforestation and Pollution, Report at www.countthecosts.org 2015; L M Dávalos and A Bejarano, "Conservation in Conflict: Illegal Drugs versus Habitat in the Americas." State of the Wild 2008-2009. Washington, DC: Island Press, pp. 218-225, 2008; For the Golden Triangle, see: T Kramer et al, 2014 For the US, see, National Drug Intelligence Center. Domestic Cannabis Cultivation Assessment. Washington, DC: US Department of Justice, 2007; Carah et al., 2015.

25 A W McCoy, "The Stimulus of Prohibition: a Critical History of Global Narcotics Trade", in Dangerous Harvest: Drug Plants and the Transformation of Indigenous Landscapes, MSteinberg, Jل J Hobbs, and K Mathewson, eds., Oxford, UK: Oxford University Press, 2004, p. 29 studies show that over time, eradication campaigns have sequentially diffused the coca-deforestation nexus into 23 of the country's 32 departments, including newer production zones within the Colombian Chocó, a biodiversity hotspot. ${ }^{19}$ In Colombia overall, 2,910 square km of primary forest are estimated to have been lost to coca cultivation between 2001 and 2014.20 In the Amazonian borderlands of Peru and Brazil, drug-driven deforestation is "part of a migratory cycle of eradication, relocation, boom, eradication, and relocation ignited by [...] coca elimination efforts in the Andean foothills."21 This dynamic explains the paradoxical finding reported by UNODC that "illicit coca bush cultivation and the transformation of coca bushes into cocaine continue to cause serious environmental damage even though coca bush cultivation has decreased."22

The eradication-inspired mobility of drug crop cultivation is commonly known as the "balloon effect," or the "displacement effect."23 The dynamic occurs worldwide, and is noted to be a root cause of environmental degradation associated with drug crop cultivation in Andean nations; Mexico's Sierra Madre Occidental; Southeast Asia's Golden Triangle (Myanmar, Lao PDR, Thailand); and in multiple US States, including California, Texas, Arizona and Oregon. ${ }^{24}$

As long as there is eradication, there is no foreseeable end to displacement because there is a "spatial infinity" of potential new cultivation areas - regionally and globally. ${ }^{25}$ For example, UNODC reports that Afghanistan, already the world's largest producer of

\section{"When drug fields are destroyed (whether by aerial fumigation or by hand), forest and habitat loss are typically increased, not lessened".}


opium poppy, contains "a number of additional areas... [that] are potentially vulnerable to large-scale opium cultivation."26 Displacement occurs within countries and between countries, sometimes spanning large distances. For example, coca supply shortages in South America were reportedly a factor in inspiring criminal organizations to cultivate coca in the northern hemisphere-in Chiapas, Mexico. ${ }^{27}$

When drug crop cultivation moves into fragile ecosystems, ecological damage extends to environmental contamination. Chemicals used to grow and process drug crops (including agrochemicals, sulfuric acid, ammonia, acetone, hydrochloric acid, kerosene, and sodium carbonate) are ultimately discharged into soil and streams by farmers and processors, as well as by the law enforcement agents who dismantle jungle drug labs. ${ }^{28}$ It is estimated that millions of barrels of this toxic mixture are released annually. ${ }^{29}$ The short-and long-term impacts of this contamination have yet to be systematically studied.

There is little evidence to suggest that "alternative development" programs will alleviate the environmental impacts associated with drug crop eradication. In both Bolivia and Colombia, researchers found that under alternative development initiatives, coca farmers cleared more primary forest to plant "land hungry substitute crops" that could not be cultivated as intensively as coca. ${ }^{30}$ In Myanmar, bans on opium led landless rural laborers, who had formerly worked as opium gum collectors, to seek income alternatives by unsustainably harvesting non-timber forest products. ${ }^{31}$ UNODC also acknowledges that alternative development can entail an "environmental production trade-off," in which deforestation is enhanced through licit investments in cattle pasture and other forest-converting land uses. ${ }^{32}$

\section{"...coca supply shortages in South America were reportedly a factor in inspiring criminal organizations to cultivate coca in the northern hemisphere- in Chiapas, Mexico."}

26 UNODC, World Drug Report2015 p 95

27 K Hamilton, “The Discovery of Mexico's First Coca Plantation Could Upend the Cocaine Business", Vice News, 15 September, 2014

28 UNODC World Drug Report, p. 276; OAS Drug Problem in the Americas, 2013; L M Dávalos and A Bejarano, 2008.

29 DS Salisbury and C Fagan, 2013: OAS, 2013

30 AV Bradley and AC Millington "Coca and Colonists: Quantifying and Explaining Forest Clearance under Coca and Anti-Narcotics Policy Regimes." Ecology and Society 1331 [online], 2008; L M Dávalos et al., 2009.

31 UNODC, Opium Poppy Cultivation in the Golden Triangle-Lao PDR, Myanmar, Thailand. Vienna: UN Office of Drugs and Crime, 2006.

32 UNODC, World Drug Report, 2015, p. 109 
33 LFarthing and B Kohl, "Supply-side harm reduction strategies: Bolivia's experiment with social control," International Journal of Drug Policy 23:488-494. 2012; J Buxton, 2015

34 UNODC, World Drug Report, 2015

35 Bradley and Millington, 2008

36 C Moreira A., "Fertilizantes y sobreexplotación propagaron el hongo de la coca." Diario Página Siete, October 13, 2013, at: http://www.paginasiete. bo/sociedad/2013/10/13/fertilizantessobreexplotacion-propagaron-hongo-coca-2970. html

37 Commission on Narcotic Drugs, 2014

38 D Mejia and P Restrepo, "Why Is Strict Prohibition Collapsing?" In: Collins J (ed.) Ending the Drug Wars. London, UK: LSE IDEAS, 2014; J M Bunck and MRFowler, Bribes, Bullets, and Intimidations: Drug Trafficking and the Law in Central America, Pennsylvania State University Press, 2012

39 UNODC, Global Drug Report 2015, p. 44

40 Bagley, 2012
In contrast, Bolivia's experimentation with "social control" of coca production does offer an alternative to eradication policies, in which coca farmers legally cultivate a fixed area. ${ }^{33}$ While the program is still in its early stages, initial findings suggest that it has contributed to a significant reduction in the area under coca. ${ }^{34}$ The potential for the program to reduce pressures on forests is suggested by research showing that historically in Bolivia, relaxed state approaches to coca cultivation (so-called "pro-coca" regimes) have been associated with lower deforestation rates. ${ }^{35} \mathrm{At}$ the same time, the intensification of legal coca cultivation has raised concerns about pesticide resistance and soil contamination due to coca farmers' heavy reliance on agrochemicals in their circumscribed plots ${ }^{36}$

\section{Environmental impacts of drug policy in transit countries}

In its 57th session in 2014, the UN Commission on Narcotic Drugs noted that among priorities for action is "the need to respond to shifting trafficking routes and new drug trafficking trends." 37 Those new trafficking trends are often the direct result of prohibitionist supply-side drug policies. For example, aggressive anti-trafficking efforts in Colombia opened the way for greater involvement of Mexican and other traffickers in the cocaine trade, changing trafficking routes and widely distributing drug-smuggling revenues. ${ }^{38}$

According to a report by UNODC, traffickers continually move into new areas in part as a result of successful interdiction activities (e.g., surveillance and seizure operations). For example, "strengthening of [drug] controls between Afghanistan and Iran and between Iran and Turkey may have forced traffickers to move southwards towards the coasts..."39 Sometimes known as the "cockroach effect" (akin to bugs scurrying away when a light comes on), ${ }^{40}$ displacement and disruption by counter-narcotics operations inspires traffickers to move their operations deeper into the forest, down the river, or along the coast. 
Among the first priorities for traffickers developing a new transshipment node is to clear landing areas, often from forest or desert habitats. Once established, drug trafficking activities can finance and accelerate preexisting illegal extraction of natural resources from surrounding areas. This is because moving drugs brings new investment opportunities for those already trafficking in timber, endangered wildlife, and marine resources such as lobster, shark fin, fish bladders, and sea cucumber. At the same time, drug trafficking organizations (DTOs) often diversify into these sectors to expand their money laundering opportunities. ${ }^{41}$

United Nations Environment Programme (UNEP) and others have noted that the trades in illegal fisheries, logging, and wildlife "rank alongside" the drug trade in terms of global criminal earnings. ${ }^{42}$ Less widely recognized is the degree to which these trades have long been vertically and horizontally integrated through money laundering and shared personnel and logistics. ${ }^{43}$ The result is the coordinated and systematic degradation of ecologically significant landscapes.

Even more extensive ecological impacts emerge indirectly from the high profits that traffickers earn for moving drugs under the existing prohibitionist regime. Economic analysis shows that in the drug commodity chain, the relatively small number of brokers in the "midstream" transit stage means that each is able to earn substantial profits. ${ }^{44}$ Traffickers often launder those large profits through land-extensive economic activities located near trafficking hubs. Speculative frontier land markets are ideal for money laundering. In Brazilian Amazonia, "drug trafficking and money laundering represent strong forces in some areas and help spread deforestation where it would be unprofitable based only on the legitimate economy";45 traffickers there cleared a 620 square km area of forest in a single three-week period in $2003 .{ }^{46}$ Traffickers often take advantage of poorly articulated land rights to convert forest to higher-value land uses such as cattle pasture. ${ }^{47}$ Even where land rights are clearly delimited or possibilities for private
41 For example, see: Salisbury and Fagan, 2013; CM Giraldo and J Bargent, "Are Mexican Narcos Moving into Lucrative Fish Bladder Market?" at: http:// www.insightcrime.org/news-briefs/mexico-narcosfish-bladder-market, August 2014; K Benessaiah and J Sayles, "Drug Trafficking's Effect on Coastal Ecosystems." Science 343:1431, 2014; M Yagoub, "Massive Mexico Illegal Wood Seizure Sign of Criminal Diversity,' InSight Crime, April 14, 2014

42 UNEP, UNEP Year Book 2014 Emerging Issues Update: Illegal Trade in Wildlife. Nairobi, Kenya: United Nations Environment Program, 2014.

43 N South and T Wyatt, "Comparing Illicit Trades in Wildlife and Drugs: an Exploratory Study" Deviant Behavior 32: 538-561, 2011. See also B Nietschmann, "Protecting Indigenous Coral Reefs and Sea Territories, Miskito Coast, RAAN, Nicaragua" Conservation through Cultura Survival. Washington, DC: Island Press, 1997; R Schönenberg, "New Criminal Domains in the Brazilian Amazon", International Social Science Journal 53(169):397-406, 2001; M Lohmuller, "Mexico Seeks New Approach to Tackling Environmental Crime," InSight Crime, 13 October, 2015, at: http://www.insightcrime.org/newsbriefs/mexico-seeks-new-approach-tacklingenvironmental-crime

44 UNODC, Estimating Illicit Financial Flows Resulting from Drug Trafficking and Other Transnational Organizated Crimes, Research Report. Vienna: UN Office on Drugs and Crime, 2011; CM Allen, An Industrial Geography of Cocaine, New York and London: Routledge, 2005; Keefer et al., 2008.

45 P Fearnside, 2008, first page.

46 Ibid.

47 Mejia and Restrepo, 2014; L Osorio Machado, “The Eastern Amazon Basin and the Coca-Cocaine Complex", International Social Science Journal 53(169):387-395, 2001. 
48 K McSweeney K and Z Pearson, "Prying Native Peoples from Native Lands: Narco-Business in Honduras." NACLA Report on the Americas 46 7-12, 2013: L Grandia, "Road Mapping: Megaprojects and Land Grabs in the Northern Guatemalan Lowlands," Development and Change 44(2):233-259, 2013 TBallvé, "Everyday State Formation: Territory, Decentralization, and the Narco Landgrab in Colombia", Environment and Planning D: Society and Space 30:603-622, 2012

49 U.S. Department of the Treasury, "Treasury Targets "Los Cachiros" Drug Trafficking Organization in Honduras," Press Release, www.treasury.gov, 19 September, 2013; N Richani, "The Agrarian Rentier Political Economy: Land Concentration and Food Insecurity in Colombia." Latin American Research Review, 47.51-78, 2012; R Araújo, "The Drug Trade, the Black Economy, and Society in Western Amazonia", International Social Science Journal 53(169):451-257. 2001; see also Grandia, 2013

50 McSweeney and Pearson 2013; Grandia 2013; Ballvé 2012.

51 K McSweeney et al., 2014; Richani, 2012

52 L O Machado, 2001; see also UNODC, Colombic: Coca Cultivation Report, 2015 for geographica proximity of coca cultivation and alluvial gold mining operations; for more on the interplay between coca farming and gold mining, see J Bargent, "Colombia: From Coca Cultivation to Gold Mining and Back" InSight Crime, September 22, 2015

53 ACA. Fact Sheet: Illegal Gold Mining in Madre De Dios. Peru. Washington, DC: Amazon Conservation Association, 2013

54 See: U.S. Department of the Treasury, 2013; M Stevenson, "Mexican Drug Cartels Now Make Money Exporting Ore,", Miami Herald online, November 29, 2013; P Villegas, "Mexico Targets Gang that Infiltrated the Mining Industry,' The New York Times Online, March 5, 2014

55 R Duffy, "Global Governance, Criminalisation and Environmental Change", Global Crime 7(1):25-42, 2006

56 See, e.g., RSchönenberg, 2001, and L Shelley "Laundering Money into Real Estate", in

Convergence: Illicit Networks and National Security in the Age of Globalization, eds. M Miklaucic and J Brewer, Washington, DC: National Defense University Press, pp. 131-148, 2013. property are prohibited under law (as in many protected areas), traffickers use bribes, threats, violence, and economic incentives to acquire land from indigenous and peasant communities. ${ }^{48}$

Drug cartels are also known to launder money through "legitimate" cattle, coffee, and palm oil plantations and processing facilities. ${ }^{49}$ Like most narco-capitalized properties, they can expand rapidly because the impunity, violence, and cash flow associated with drug transit can allow traffickers and their affiliates to monopolize rural land and labor, often at the expense of peasant farms and community forests. ${ }^{50}$ Thus drug profits can catalyze the transformation of ecologically vibrant mixed-use, agro-diverse landscapes of smallholder food production into monocultural agribusiness landscapes.51

Traffickers' ecological impacts are not confined to the agricultural sector. In the Amazon, cocaine traffickers are also known to launder profits through illegal alluvial gold mining operations, with the benefit that gold and drugs can be moved through the same smuggling networks.52 In Madre de Dios, Peru, gold mining is associated with rampant deforestation and the annual dumping of 30-40 tons of mercury into rivers and streams, seriously contaminating fish and the humans that eat them. ${ }^{53}$

Some DTOs are also investing in industrial mining projects, ${ }^{54}$ as well as hotel developments that threaten coastal ecosystems. ${ }^{55}$ DTOs that are well embedded in local structures of power can bribe officials to ensure lax oversight of prevailing environmental standards in their construction and operation, with serious environmental

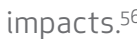




\section{Drug policy and biodiversity conservation}

Eradication and interdiction push drug cultivators and traffickers into remote areas that are refuges for biodiversity, including national parks, nature reserves, and biosphere reserves. ${ }^{57}$ In Colombia, for example, $8 \%$ of new coca fields were within national parks in 2005; in 2014, coca was grown in 16 of Colombia's 59 national parks. ${ }^{8}$ Similarly, border interception inspired Mexican DTOs to begin cultivating marijuana in California's state and federal forest lands, where impacts to date include land clearing, agrochemical pollution, and wildlife poaching; surface water diversion threatens rare and endangered fish, amphibians, and other animals. ${ }^{59}$ The result is that "[black market] marijuana cultivation can have environmental impacts that are disproportionately large given the area under production."60

Drug-related activities take a serious toll on governance of protected areas. At the national level, counter-narcotics initiatives can create policy displacement, pulling scarce resources out of environmental protection. On the ground, the presence of violent criminal organizations and counter-narcotics activities can discourage law enforcement by park guards and site visits by conservation managers. ${ }^{61}$ For example, in 2011, UNESCO's World Heritage Committee put Honduras's Río Plátano Biosphere Reserve on the "World Heritage in Danger" list, in part because of "the reduced capacity of the State to manage the site, notably due to the deterioration of law and to the presence of drug traffickers." ${ }^{\prime 2}$ Similarly, ecotourists are reluctant to travel to areas with drug activity, depriving local conservation efforts of vital revenue and international visibility. In the Mayan landscapes of Guatemala's Petén, for example, "tourism numbers are plummeting in response to the drug violence."63

Environmental activists, including indigenous and peasant leaders, park rangers, and journalists, may be threatened and in some cases have been killed when they have spoken out against the ecologically destructive activities associated with drug production and
57 US Department of Justice, National Drug Intelligence Center, 2007:W Allen, "In the Land of the Maya, a Battle for a Vital Forest", Yale Environment 360, October 8, 2012; DS Salisbury and C Fagan, 2013.

58 See: LM Dávalos et al., 2009; UNODC, Colombia: Coca Cultivation Survey, 2015.

59 J K Carah et al., 2015

60 Ibid, p. 823

61 See, for example: P Fearnside, 2008: W Allen, 2012 Carah et al., 2015; L M Dávalos and A Bejarano 2008; J Barborak, "In Person: Conservation in Conflict Areas" Conservation International Website, at: www.conservation.org/warfare/ Pages/barborak.aspx, 2011.

62 UNESCO, "World Heritage Committee Puts Río Plátano Biosphere Reserve on Danger List at the Request of Honduras," at: http://whc.unesco.org/ en/news/763/,22 June 2011

63 L Grandia, 2013, p. 254; see also Dávalos and Bejarano, 2008. 


\section{"At the national level, counter-narcotics initiatives can create policy displacement, pulling scarce resources out of environmental protection."}

traffic. ${ }^{64}$ This violence-enforced silence can deeply discourage civil society organizations from their crucial role in management and governance of protected areas.

\section{Drug policy and climate change}

The loss of forests and the degradation of natural habitats in drug production and drug trafficking zones contributes to the crisis of biodiversity decline worldwide. At local and regional scales,
64 Global Witness, Deadly Environment: The Dramatic Rise in Killings of Environmental and Land Defenders. London, UK: Global Witness, 2014; for an example, see: B Reeves “Drug Traffickers Are Wiping out the Jaguar in Central America." Global Post, at www.globalpost.com/ article/6590416/2015/06/22/jaguar-drug-war, 2015

65 See, e.g., A P Karney and P E Murillo Zaldivar, "Illegal invaders threaten sixteen years of responsible forest management in Copén, Honduras".

Commonwealth Forestry Association Newsletter, No. 62, December, 2013 this lowers the resilience of affected socio-ecological systems, making them more susceptible to the destructive flooding, tropical storms, and drought that are predicted to increase under most climate change scenarios.

Drug policies sanctioned by one part of the UN that ultimately-if inadvertentlycatalyze forest loss and degradation thus work directly at cross-purposes with climate change mitigation efforts by other UN agencies. For example, a potentially important component of United Nations Framework Convention on Climate Change (UNFCCC) are REDD+ initiatives, an extension of the REDD program that can include compensating forest-based communities for avoided deforestation. That compensation, however, could not begin to compare with traffickers' abilities to financially coerce forest conversion to pasture or other uses. In every way, drug traffickers' presence in forested landscapes profoundly undermines the conditions necessary for REDD+ to work, including longterm, community-centered control and management of forests. ${ }^{65}$ 


\section{Drug policy and indigenous peoples}

The UN Declaration on the Rights of Indigenous Peoples asserts that states, "shall provide effective mechanisms for prevention of, and redress for any action which has the aim or effect of dispossessing them of their lands, territories or resources" (Article $8,2 b)$, and that indigenous peoples "shall be consulted on any actions that are connected to 'the development, utilization or exploitation of mineral, water or other resources'" (Article 32). ${ }^{66}$

Drug policies work in direct opposition to these rights. Some approaches to implementing the UN Single Convention on Narcotic Drugs (1961) have been shown to threaten the exercise of indigenous peoples'rights, particularly when drug prohibitions interfere with traditional use of plants. ${ }^{67}$ But the ways in which drug policies can encourage the ecological destruction of indigenous homelands, however, are less widely acknowledged. Eradication and interdiction efforts in Peru and Brazil, for example, have incentivized trafficking activities through lands inhabited by tribes living in voluntary isolation, for whom contact with drug runners can have tragic social and epidemiological consequences. ${ }^{68}$ Elsewhere, drug-related activities have been displaced into an ever-growing number of impoverished Afro-descendent and indigenous communities in South America and Mesoamerica, ${ }^{69}$ and among hill tribes in Southeast Asia. ${ }^{70}$

Once established in indigenous territories, drug traffickers often use violence to press inhabitants into involvement in their criminal activities, ${ }^{71}$ while simultaneously dispossessing them of land and resources that would otherwise be managed sustainably by and for communities. ${ }^{72}$ While some indigenous communities have been able to resist narco-fuelled resource grabbing, they appear exceptional. ${ }^{73}$

\section{UN, 2008}

67 S Pfeiffer, "Rights of Indigenous Peoples and the International Drug Control Regime: The Case of Traditional Coca Leaf Chewing". Goettingen Journal of International Law 5287-324, 2013

68 BBC News, "Remote Brazilian Tribe Threatened by 'Drug Dealers',' BBC News [Online], August 8, 2011; D SSalisbury and C Fagan, 2013

69 Just a few of the many impacted groups are: Awa (Colombia), Emberá-Wounaan (Panama), Miskitu (Honduras and Nicaragua), Garifuna (Honduras and Belize), Tawahka (Honduras), Q'eqchi' Maya (Guatemala), Rarámuri (Mexico). For sources, see: E P Perramond, "Desert Traffic: the Dynamics of the Drug Trade in Northwestern Mexico," pages 209-217 in MSteinberg JJ Hobbs, and K Mathewson, eds., Dangerous Harvest: Drug Plants and the Transformation of Indigenous Landscapes, Oxford, UK: Oxford University Press, 2004: J M Bunck and M R Fowler, 2012; Rincón Ruiz and Kallis, 2013: E Salmon، “Voices", Cultural Survival online at: http://www.culturalsurvival.org/publications/ voices/enrique-salmon/narco-trafficking-sierratarahumara; McSweeney and Pearson, 2013: L Grandia, 2013.

70 TKramer et al., 2014

71 See, e.g., Salisbury and Fagan, 2013; McSweeney and Pearson, 2013: BBC, "Drug smugglers kill indigenous people in Paraguay,'BBC News [Online], November 23, 2011

72 J. Meléndez, "El narcotráfico compra servicios de indigenas panameños en Darién", El Pais, March 29. 2014. See also D S Salisbury and C Fagan, 2013.

73 PRISMA Pueblos Indígenas y Comunidades Rurales Defendiendo Derechos Territoriales. El Salvador: PRISMA, 2014 


\section{CONCLUSION}

The London School of Economics' Expert Group on the Economics of Drug Policy points out that the UN's role is to "assist states as they pursue best practice policies based on science and evidence, not work to counteract them." 74 The drug policy-environment nexus demonstrates just how profoundly counter-narcotics policies can work in opposition to policies intended to protect the environment and enable sustainable development. The task is now to use insights from science to identify the best ways to address this collateral environmental damage, particularly through enhanced articulation of shared concerns across UN agencies. ${ }^{75}$

Accomplishing this task begins with broad-based, international recognition that, while drug cultivators and drug traffickers may be destroying forests and other habitats world-wide, it is the global prohibitionist regime and related counter-narcotics approaches that profoundly incentivize these activities-at great costs to local, regional, and global environments. 


\section{RECOMMENDATIONS}

$\rightarrow 1$. The international drug policy community must acknowledge the breadth and severity of the environmental impacts associated with drug control policies: long-term emphasis on drug crop eradication and transit zone interdiction has imposed high costs on the global environment, and member states should commit themselves to reforming policies to eliminate this damage.

$\rightarrow$ 2. The UNGASS debate on drugs should recognize that these costs extend to-and often concentrate in-a growing number of drug transit states, not only in drug producing states, and should demand novel policies to halt this proliferation.

$\rightarrow$ 3. UN member states must acknowledge that, while the environmental impacts of drug policy are global-especially as they contribute to climate change-the global drug policy regime places a grossly disproportionate environmental burden on countries of the global South. These burdens are measured by lost economic opportunities from sustainable resource management, eroded conservation governance, the loss of ecosystem services, and excessive environmental contamination.

$\rightarrow$ 4. Costs to the environment must be added to standard metrics that are used to judge drug policy effectiveness; accounting for environmental damages is essential for realistic whole-cost assessments of drug policy alternatives. To be most effective, this accounting must be calibrated to supranational scales, as single-state assessment can hide the displacement of environmental harms from one state to another that occurs under standard supply-side interventions. 
$\rightarrow$ 5. Multilateral agencies must allow more opportunities for national-level innovation and regional-level cooperation in supply control, particularly around inventive ways to establish sustainable, legal systems of drug crop cultivation (following Bolivia's example), and on creative alternatives to failed "cat-and-mouse" interdiction approaches in transit zones.

$\rightarrow$ 6. UN member states must commit to strengthening support for biodiversity conservation in landscapes affected by the drug trade and counter-narcotics operations, especially by championing and financially supporting the right of indigenous and peasant communities to secure land tenure, and to sustainably manage resources as they see fit.

$\rightarrow 7$. UN member states should consider reallocating interdiction resources to instead enhance efforts to identify and prevent money laundering and illicit investment in environmentally degrading rural sectors such as agribusiness, mining, and illegal timber harvesting.

$\rightarrow$ 8. The debate on drug policy reform must make meaningful room for sustained input and decision-making by UN agencies whose remit directly encompasses the environmental impacts of drug control policies, including UNDP, UNEP, the UN collaborative initiative on REDD, and the UN's Permanent Forum on Indigenous Issues, among others. 


\section{Open Society Foundations}

224 West 57th Street

New York, NY 10019 USA

+1 2125480600

opensocietyfoundations.org

\section{OPEN SOCIETY \\ FOUNDATIONS}

